\title{
Role of the Pituitary on the Manifestation of Hypocholesterolemic Action of Estrogen
}

\section{Kiyohisa UCHIDA}

Shionogi Research Laboratory, Fukushima-Ku, Osaka

It was confirmed that the three estrogens, estradiol, estriol and hexestrol, produced marked decreases in both plasma cholesterol and phospholipids levels in intact rats. Also, it was found that the hypocholesterolemic activity of estrogens gradually decreased after hypophysectomy, and completely disappeared 9 days after the operation. Neither adrenalectmy, castration, nor thyroidectomy affected the manifestation of this estrogen action. The estrogen effect was manifested again when the hypophysectomized rats were primed with pituitary homogenate of the same species or bovine growth hormone before the estrogen treatment. The piming with TSH, HCG or PMS produced no restoration of the estrogen action which disappeared in the hypophysectomized animals. AGTH had no action on the plasma cholesterol level in intact rats, but produced marked increase in the hypophysectomized rats. This ACTH-induced hypercholesterolemia in the hypophysectomized animals was reduced to the normal level by the simultaneous treatment of estrogen. The estrogen action manifested also in rats treated with prednisolone, the dosage of which was enough to produce complete suppression of ACTH secretion.

These facts suggest that the pituitary is necessary for the manifestation of hypocholesterolemic action of estrogen in rats, and that growth hormone may play an important role in the lipid-shifting action of estrogen, while ACTH may be not a factor directly related to this estrogen action.

(pp. 1112 1127) 


\title{
Estrogen のラット血中 cholesterol 低下作用 発現に関する下垂体の役割
}

\author{
塩 野義 研 究所

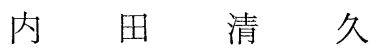

(昭和38年11月16日受付)

緒言

ラットに estrogen を投与すると血中 cholesterol 值は顕著に低下する年4).去勢雄ラットでは，乙のcholesterol 低下作用は多くの steroid の中でも estrogen に特有のものである ${ }^{5)}$. 好が，その作用機棈は未だ 明らかにされていない. Rosenman たぢは estrogen が肝に於ける cholesterol の生合成を抑制すると報告

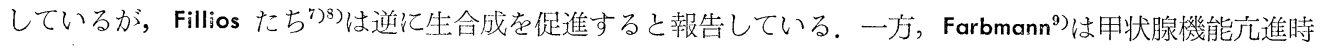
に estrogen の脂質に対する作用が現われない事から estrogen は籽腺の機能を介して作用するのではな いかと推論している.

我々はその作用機構を検討するに当り， estrogen が多くの steroid の中でも特に著しい下垂体 gonadotrophin 分泌抑制作用を示す事 ${ }^{10)}$, ACTH, TSH, growth hormone 等, 脂質代謝に関与する物質が下垂体 から分泌されている事より, estrogen の cholesterol 低下作用と下重体との関係を検討した。 その結果，極 めて興味有る知見を得たので報告する。

\section{实験材料並びに方法}

実験動物には体重 $120 １ 40 \mathrm{~g}$ の Wistar 系雄ラットを使用し，8～10匹を 1 群として飼育した. 食餉には 通常のラット用固型飼料（塩野義製薬油日農場製）在使用し，飲料水には0.1\%のポポン液（綜合ビタミン 剤，塩野義製薬，大阪）を含む生理食塩水を投与した。使用した hexestrol 及び各 steroid は全て $\mathrm{NaCl}$ : 0.9\%, Polysorbate-80 : 0.4\%, carboxymethylcellulose : 0.5\%, benzylalcohol : 0.9\%を含む水溶液を担体と してガラス製手動ホモゲナイザー（Ten-Brock 式）を用いて微細結晶の懸濁液とし，注射に供した． Steroid はラット当り $300 \mathrm{gg} 0.1 \mathrm{ml}$ の容量で 1 日 1 回脊部皮下に投与し，化合物投与実験群にそれぞれ対応する対照 群には必ず同容量の担体を投与した，夆験に際し動物に加えた手術，前処置，及び各種ホルモンの投与条件 に関する詳細は次章各実験成績の冒頭に述べる。

動物は全て最終注射24時間後に sodium methyl hexabital 麻䣷下に心藏穿刺に依つて採血し，血漿中の cholesterol 及び phospholipid 值を測定した. 方法の詳細は前報らと記載の通りである.

使用したホルモン製剤は次の通りである。

hexestrol (Red Star Chem. Co., Inc.)

estradiol-17 $\beta$ (J.P. VI, N.V. Organon)

estriol (N.V. Organon)

dexamethasone (Schering A.G. Berlin)

prednisolone (Schering A.G. Berlin)

ACTH (H.P. Acthar Gel, Armour Pharmaceutical Company, U.S.A.) 
TSH (U.S.P. Thyrotropin Reference Standard)

HCG (Primogonyl, Choriongonadotropin, Schering A.G. Berlin)

PMS (Anteron, Gonadotropes Hormon aus Serum, Schering A.G. Berlin)

STH (U.S.P. Growth Hormone Reference Standard 及び Antuitrin Growth, Parke, Davis \& Company, U.S.A.)

\section{実 験 成 績}

\section{Hexestrol の作用に対する下垂体摘出の影響}

下垂体摘出は外聴道より摘出する小山法田中変法 ${ }^{11)}$ 亿従い, 実験終了後動物の頭蓋を開き肉眼で下垂体が 完全に摘出出来ているか否かを確かめ，摘出不完全のものは除外した． Estrogen は下垂体摘出後 8 日目よ り 3 日間連続して投与した.

下垂体を摘出すると Table 1 に示す如く, 体重, 精鼠, 前立腺, 副緊, 甲状腺の各重量は減少するが血 漿脂質值には顕著な変化は認められない. Hexestrol を正常動物に投与した場合, 血漿 cholesterol, phospholipid 両值は顕著に低下するが (TG : $79.1 \pm 3.02$ vs. $31.2 \pm 4.37$, PL : $133.9 \pm 7.16$ vs. $89.1 \pm 10.12$ ), 下 垂体摘出動物に投与した場合，乙れら脂僙值は何等変化を受けない（TC: $71.4 \pm 4.47$ vs. $71.1 \pm 4.24, \mathrm{PL}$ : $114.4 \pm 4.47$ vs. $122.6 \pm 7.21$ ). 更に 7 回の繰り返し実験を行い，下垂体摘出の影響を検討する為に下垂体摘 出動物の示した值の対照正常群の值に対する割合（\%) を検討すると cholesterol 值は $94.9 \pm 3.74 \%$, phospholipid 值は73.2 $33.89 \%$ であつた. 更に, 下垂体摘出動物に於ける hexestrol, estradiol, estriol, dexamethasone 投与の血漿脂質值に対する影響を検討する為に繰り返し実験を行い, 処置群の值の対照群の值に 対する割合（\%) をまとめたものが Table 2 の結果である。尚，比較の為々去勢雄ラットに対するてれら steroid の影響も先の報告 ${ }^{5}$ から引用して併記した。. 去勢動物に於ては hexestrol, estradiol, estriol いづれ も顕著な血漿脂質值の低下を来すが，下垂体摘出ラットに於ては 3 者ともその作用を失つている. 更に, 去 勢雄ラットに3日間 hexestrol を投与した場合, hexestrol の用量と血漿 cholesterol 值の低下度との関係 を検討すると，Fig.1亿示す如く hexestrol の用量 10-750 $\mu \mathrm{g} / \mathrm{day} / \mathrm{rat}$ の間に直線的な用量作用関係を認める

Table 1. Effects of hexestrol on the plasma cholesterol, phospholipid, G/P ratio and the certain organ weights in intact and hypophysectomized male rats

\begin{tabular}{l|c|c|c|c}
\hline & \multicolumn{2}{|c|}{ Intact } & \multicolumn{2}{c}{ Hypophysectomized $^{\text {a }}$} \\
\cline { 2 - 5 } & Contral & Hexestrol $^{\mathrm{b})}$ & Control & Hexestrol $^{\mathrm{b}}$ \\
\hline \hline No. of rats & 7 & 5 & 8 & 10 \\
Body weight (g) & $177.3 \pm 5.34^{\mathrm{c})}$ & $\left.150.4 \pm 3.06^{\mathrm{c}}\right)$ & $\left.109.6 \pm 2.50^{* \mathrm{c}}\right)$ & $\left.109.6 \pm 2.32^{* \mathrm{c}}\right)$ \\
S. Vesicle (mg) & $153.9 \pm 10.5$ & $86.0 \pm 7.97^{*}$ & $21.3 \pm 0.94^{*}$ & $24.7 \pm 2.32^{*}$ \\
V. Prostate (mg) & $131.0 \pm 6.31$ & $89.8 \pm 19.3^{*}$ & $10.4 \pm 0.39^{*}$ & $12.4 \pm 1.60^{*}$ \\
Adrenals (mg) & $33.6 \pm 1.62$ & $44.3 \pm 1.41^{*}$ & $15.6 \pm 0.76^{*}$ & $15.5 \pm 1.00^{*}$ \\
Thyroid (mg) & $21.1 \pm 1.95$ & $21.4 \pm 1.53$ & $10.3 \pm 1.57^{*}$ & $9.0 \pm 0.60^{*}$ \\
Plasma total cholesterol (mg/di) & $79.1 \pm 3.02$ & $31.2 \pm 4.37^{*}$ & $71.4 \pm 4.47$ & $71.1 \pm 4.24$ \\
Plasma phospholipid (mg/dl) & $133.9 \pm 7.16$ & $89.1 \pm 10.12^{*}$ & $114.4 \pm 4.47$ & $122.6 \pm 7.21$ \\
C/P ratio & $0.60 \pm 0.032$ & $0.36 \pm 0.038^{*}$ & $0.65 \pm 0.060$ & $0.61 \pm 0.063$ \\
\hline
\end{tabular}

* Statistically significant at $95 \%$ or more of probability against intact control group.

a) Hypophysectomy was performed eleven days before autopsy.

b) Daily $300 \mu \mathrm{g}$ per rat of hexestrol was injected subcutaneously for the last three days before autopsy.

c) Mean \pm S.E. 
Table 2. Comparisons of the effects of hexestrol, estradiol, estriol and dexamethasone on the plasma cholesterol and phospholipid levels in the hypophysectomized and in the castrated male rats

\begin{tabular}{l|c|c|c|c|c}
\hline & \multicolumn{3}{|c|}{ Hypophysectomized $^{-}$} & \multicolumn{2}{c}{ Castrated $^{\mathrm{a})}$} \\
\cline { 2 - 6 } & $\begin{array}{c}\text { No. of } \\
\text { experiments }\end{array}$ & $\left.\mathrm{TC}(\%)^{\mathrm{b}}\right)$ & $\left.\mathrm{PL}(\%)^{\mathrm{b}}\right)$ & $\mathrm{TC}(\%)^{\mathrm{b})}$ & $\mathrm{PL}(\%)^{\mathrm{b})}$ \\
\hline Hexestrol & 13 & $\left.85.2 \pm 2.96^{\mathrm{c}}\right)$ & $\left.91.1 \pm 3.31^{\mathrm{c}}\right)$ & 45 & 54 \\
Estradiol & 2 & 104.5 & 104.5 & 69 & 94 \\
Estriol & 1 & 87. & 102 & 64 & 73 \\
Dexamethasone & 1 & 294 & 369 & 159 & 211 \\
\hline
\end{tabular}

* Daily $300 \mu \mathrm{g}$ per rat of compounds were injected subcutaneously for the last three days before autopsy.

a) The data quoted from the previous report (Uchida \& Miyake, 1961) s) $^{\text {) }}$

b) The values expressed as the percentage of the treated group levels against control group levels.

c) Mean \pm S.E.

TC: total cholesterol

PL : phospholipid

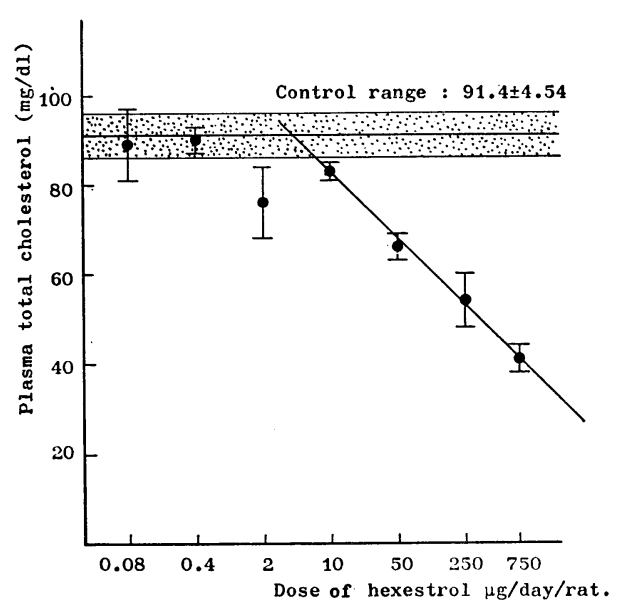

Fig.1. Dose Response Relationship of hexestrol on the plasma cholesterol level in castrated male rats. Hexestrol was injected subcutaneously for three days as a fine crystal suspension.

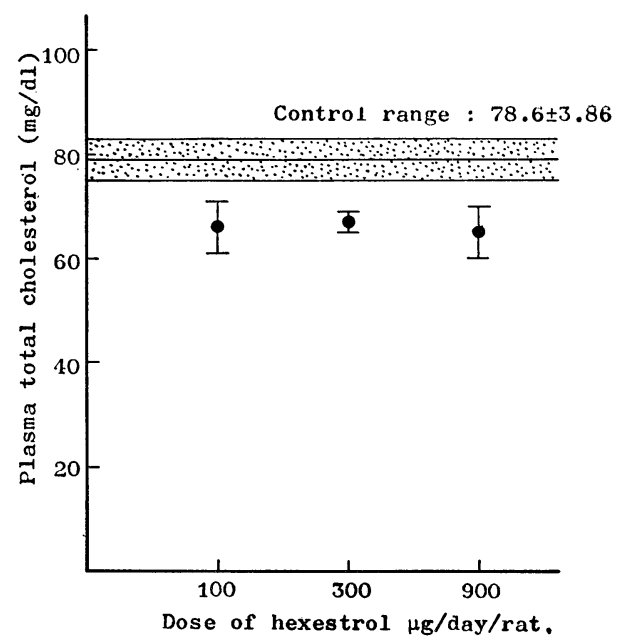

Fig. 2. Dose Response Relationship of hexestrol on the plasma cholesterol level in the hypophysectomized male rats. Hexestrol was injected subcutaneously for the last three days before autopsy as a fine crystal suspension.

事が出来る，乙れに対し，下垂体摘出ラットに術後7日目より100，300，900 $\mu \mathrm{g} / \mathrm{day} / \mathrm{rat}$ の hexestrol を 3 日間投与した場合は Fig. 2 に示す如く用量作用関係は勿諭，高用量に於てすら推計学的に有意な血漿 cholesterol 值の低下を認める事は出来なかつた。更に，下金体摘出後の日数と estrogen の作用との関係につ いて検討する為に下垂体摘出の当日， 3 日，6日，及び 9 日後よりラット当り $300 \mu \mathrm{g} の$ hexestrol を 1 日 1 回，3 日間に渉り連続投与した。下重体摘出後それぞれ 3 日，6日，9日，及び12日後に血漿 cholesterol， phospholipid 值を測定すると Table 3 に示す如く，下重体摘出後 3 日，及び 6 日目の群では hexestrol 投 与に依り血漿脂質值は低下している。然し，低下度は正常動物に於ける場合と比較して小さく下垂体摘出後 
Table 3. Response of plasma cholesterol and phospholipid levels to the hexestrol administration started at the different intervals after hypophysectomy.

\begin{tabular}{c|c|c|c|c}
\hline \multirow{2}{*}{$\begin{array}{c}\text { Days after } \\
\text { hypophysectomy }\end{array}$} & \multicolumn{2}{|c|}{ Total cholesterol $(\mathrm{mg} / \mathrm{dl})$} & \multicolumn{2}{c}{ Phospholipid (mg/dl) } \\
\cline { 2 - 5 } & Control & Hexestrol & Control & Hexestrol $\left.^{\mathrm{a}}\right)$ \\
\hline 3 & $65.7 \pm 2.33$ & $50.4 \pm 0.98^{*}$ & $66.0 \pm 3.32$ & $57.3 \pm 2.03^{*}$ \\
6 & $91.5 \pm 1.75$ & $63.9 \pm 3.63^{*}$ & $87.8 \pm 2.38$ & $62.8 \pm 2.78^{*}$ \\
9 & $81.3 \pm 6.12$ & $85.5 \pm 5.77$ & $63.2 \pm 4.85$ & $62.3 \pm 3.75$ \\
12 & $82.3 \pm 6.66$ & $75.0 \pm 6.30$ & $71.1 \pm 3.46$ & $69.8 \pm 4.41$ \\
\hline
\end{tabular}

Each of the values is represented by the mean value with its standard error of the group consisting of 6 to 7 rats.

a) Daily $300 \mu \mathrm{g}$ per rat of hexestrol was injected subcutaneously for the last three days before autopsy.

* Statistically significant at $95 \%$ or more of probability aginst control

9 日，及び12日目の群では hexestrol の作用が現われていない. 従つて, estrogen の血漿 cholesterol 低下 作用が消失するのは下垂体摘出後 9 日目以降の動物に於てである事が推察出来る.

一方, dexamethasone は去勢倠ラットに於て顕著な血漿脂質值の増大を示すが ${ }^{5}$ ，乙の作用は下垂体摘出 ラットに於ても認められる。従つて，dexamethasone の作用に対しては，下垂体は関係なくその作用機構 も estrogen とは全く異つていると思われる. Dexamethasone は estrogen ではないが血漿脂質值に対し著 しい作用を示すので5)比較の為に検討を行つた。

以上の如く，下垂体摘出ラットに於て estrogen の血漿 cholesterol 低下作用が消失する事実は正常動物 や去勢動物に於ける場合と比較して極めて著しい相違である。乙の現象より，estrogen の作用に対する下重 体の役割として次の 2 つ場合が想定出来る。即ち，

（1）下垂体が estrogen 投与に依り影響を受け，副腎，性腺，甲状腺等の下垂体の支配下に有る内分泌臓 器の機能を介して作用が発現する間接的な場合, 及び

（2）乙れらの内分泌蔵器を介せずに下垂体自身の機能，又は下垂体産出の物質が単独又は estrogen と共 同して作用が発現する直接的な場合である.

もしも，(1)の仮定が正しいとすれば，副腎，性腺，甲状腺等を剔出した動物に対しても estrogen の作用

Table 4. Effects of hexestrol on the plasma cholesterol, phospholipid and $\mathrm{C} / \mathrm{P}$ ratio in the intact and adrenalectomized male rats

\begin{tabular}{|c|c|c|c|c|}
\hline & \multicolumn{2}{|c|}{ Intact } & \multicolumn{2}{|c|}{ Adrenalectomized ${ }^{a}$ ) } \\
\hline & Control & Hexestrol $\left.{ }^{b}\right)$ & Control & Hexestrol $^{b)}$ \\
\hline No. of rats & 10 & 10 & 6 & 7 \\
\hline Body weight (g) & $148.7 \pm 10.14^{\mathrm{c})}$ & $140.3 \pm 9.56^{\mathrm{c})}$ & $\left.148.5 \pm 4.71^{c}\right)$ & $\left.139.0 \pm 4.09^{c}\right)$ \\
\hline Plasma total cholesterol $(\mathrm{mg} / \mathrm{dl})$ & $60.4 \pm 1.28$ & $27.0 \pm 3.53^{*}$ & $56.0 \pm 3.42$ & $22.0 \pm 3.55^{*}$ \\
\hline Plasma phospholipid (mg/dl) & $108.8 \pm 3.34$ & $65.9 \pm 5.77 *$ & $98.6 \pm 7.06$ & $44.8 \pm 5.24 *$ \\
\hline $\mathrm{C} / \mathrm{P}$ ratio & $0.56 \pm 0.014$ & $0.40 \pm 0.034 *$ & $0.57 \pm 0.023$ & $0.48 \pm 0.044$ \\
\hline
\end{tabular}

a) Adrenalectomy was performed six days before autopsy.

b) Daily $300 \mu \mathrm{g}$ per rat of hexestrol was injected subcutaneously for the last three days before autopsy.

c) Mean \pm S.E.

* Statistically significant at $95 \%$ or more of probability against intact control group. 
Table 5. Effects of estradiol and dexamethasone on the plasma cholesterol, phospholipid and $\mathrm{C} / \mathrm{P}$ ratio in the adrenalectomized male rats

\begin{tabular}{l|c|c|c|c}
\hline & \multirow{2}{*}{ Intact } & \multicolumn{3}{|c}{ Adrenalectomized $^{\mathrm{a})}$} \\
\cline { 3 - 5 } & & Control & Estradiol $\left.^{\mathrm{b}}\right)$ & $\begin{array}{c}\text { Dexame- } \\
\text { thasone }^{\mathrm{b}}\end{array}$ \\
\hline No. of rats & 9 & 9 & 9 & 9 \\
Body weight $(\mathrm{g})$ & $\left.182.9 \pm 2.93^{\mathrm{c}}\right)$ & $\left.164.2 \pm 3.60^{\mathrm{c}}\right)$ & $147.8 \pm 2.96^{\mathrm{c})}$ & $\left.141.7 \pm 2.13^{\mathrm{c}}\right)$ \\
Plasma total cholesterol $(\mathrm{mg} / \mathrm{dl})$ & $64.6 \pm 2.08$ & $57.8 \pm 1.76$ & $44.8 \pm 2.08^{*}$ & $90.6 \pm 2.57^{*}$ \\
Plasma phospholipid $(\mathrm{mg} / \mathrm{dl})$ & $92.4 \pm 5.20$ & $79.8 \pm 3.78$ & $53.1 \pm 2.70$ & $169.2 \pm 4.35^{*}$ \\
C/P ratio & $0.71 \pm 0.043$ & $0.74 \pm 0.035$ & $0.85 \pm 0.042^{*}$ & $0.54 \pm 0.031^{*}$ \\
\hline
\end{tabular}
a) Adrenalectomy was performed six days before autopsy.
b) Daily $300 \mu \mathrm{g}$ per rat of compounds were injected subcutaneously for the last three days before autopsy.
c) Mean \pm S.E.
* Statistically significant at $95 \%$ or more of probability against adrenalectomized control group.

は消失する䈏である。乙の可能性を検討する為に, 各内分泌㵴器剔出動物について検討を試みた。

\section{Hexestrol の作用に対する副腎摘出の影響}

雄ラットの両側副腎剔出後 3 日目より hexestrol, estradiol, dexamethasone を 3 日間投与した. 測定結 果は Table 4, 及び Table 5 に示す通りである. 副腎除去に依り血漿 cholesterol, phospholipid 両值は減 少の傾向を示すが有意の変化ではない，然し，hexestrol, estradiol を投与した群では血漿脂質値は顕著に低 下し，正常動物にこれら estrogen を投与した場合と同程度，又はそれ以上の低值を示した。一方， dexamethasone は有意の増加を来した. 従つて, 副腎除去動物に於けるてれら steroid の影響は正常動物に於け る変化と比較して著しい相違は認められないので estrogen の作用が下垂体副㛑系を介して発現する可能性 は否定出来る.

\section{Hexestrol の作用に対する性腺摘出の影響}

Table 6. Effects of castration on the plasma cholesterol, phospholipid, $\mathrm{C} / \mathrm{P}$ ratio and certain organ weights in male rats

\begin{tabular}{l|c|c}
\hline & Intact & Castrated $^{\mathrm{a}}$ ) \\
\hline \hline No. of rats & 8 & 7 \\
Body weight (initial) & $124.1 \pm 2.58^{\mathrm{b}}$ & $\left.122.3 \pm 3.70^{\mathrm{b}}\right)$ \\
" (final) & $165.4 \pm 3.62$ & $155.6 \pm 5.60$ \\
S. Vesicle (mg) & $153.0 \pm 17.35$ & $23.1 \pm 2.51^{*}$ \\
V. Prostate (mg) & $129.4 \pm 10.59$ & $12.4 \pm 1.33^{*}$ \\
Adrenals (mg) & $34.2 \pm 1.29$ & $42.6 \pm 1.56^{*}$ \\
Thymus (mg) & $430.4 \pm 34.13$ & $474.1 \pm 52.50$ \\
Plasma total cholesterol (mg/dl) & $98.7 \pm 2.65$ & $103.8 \pm 2.35$ \\
Plasma phospholipid (mg/dl) & $122.5 \pm 6.30$ & $118.6 \pm 4.75$ \\
G/P ratio & $0.82 \pm 0.031$ & $0.88 \pm 0.025$ \\
\hline
\end{tabular}

a) Castration was performed ten days before autopsy.

b) Mean \pm S.E.

* Statistically significant at $95 \%$ or more of probability against control. 
Table 7. Effects of hexestrol, estradiol and dexamethasone on the plasma cholesterol and phospholipid levels in the castrated male rats $^{\mathrm{a}}$ )

\begin{tabular}{l|c|c|c|c}
\hline \multirow{2}{*}{} & \multicolumn{2}{|c|}{ Total cholesterol $(\mathrm{mg} / \mathrm{dl})$} & \multicolumn{2}{c}{ Phospholipid (mg/dl) } \\
\cline { 2 - 5 } & Control & Treated & Control & Treated \\
\hline Hexestrol $^{\mathrm{b})}$ & $\left.95.9 \pm 2.41^{\mathrm{c}}\right)$ & $\left.43.6 \pm 3.26^{* \mathrm{c}}\right)$ & $\left.111.7 \pm 5.13^{\mathrm{c}}\right)$ & $\left.60.6 \pm 2.31^{\mathrm{c}}\right)$ \\
Estradiol $^{\mathrm{b})}$ & $95.9 \pm 2.41$ & $69.9 \pm 3.55^{*}$ & $113.1 \pm 6.85$ & $76.9 \pm 6.24^{*}$ \\
Dexamethasone $^{\mathrm{b})}$ & $98.8 \pm 4.47$ & $157.0 \pm 9.60^{*}$ & $110.1 \pm 3.88$ & $232.3 \pm 17.93^{*}$ \\
\hline
\end{tabular}

* Statistically significant at $95 \%$ or more of probability against control.

a) Castration was performed six days before autopsy.

b) Daily $300 \mu \mathrm{g}$ per rat of the compounds were injected subcutaneously for the last three days before autopsy.

c) Mean \pm S.E.

雄ラットの両側睪丸摘出後 3 日目より hexestrol, estradiol, dexamethasone を 3 日間投与した。去勢の 影響は䅸丸摘出後10日目の動物について比較検討した，Table 6 亿示す如く，去勢に依り精囊，前立腺の重 量は減少し，副腎重量は増加するが血漿 cholesterol，phospholipid 值は何等変化を受けない，去勢動物に 対する estrogen の作用は先にも報告した如く5)，いづれも顕著な血漿脂質值の低下作用を示し，又， dexamethasone は増加作用を示す．乙れらの結果は Table 7 に示す如くである，従つて，性腺の関与する可能 性も否定出来る.

\section{Hexestrol の作用に対する甲状腺摘出の影響}

雄ラットの甲状腺剔出後 8 日目より hexestrol, estradiol, dexamethasone を 3 日間投与した. 甲状腺剔 出及び甲状腺剔出ラットに対する steroid の作用は Table 8 に示す如くである. 甲状腺剔出に依り血漿 cholesterol 及び phospholipid 值は凡ね低下の傾向を示すが逆に増加した場合もあつた. ての実験群に於て， 体重の増加度は対照群及び甲状腺剔出群共に初体重に対して 8 ～10\%の増量を示し，特に両群間に有意の差 は認められなかつた. Boyd ${ }^{4}$ は雄ラットの甲状腺を剔出すると, 血漿 cholesterol 值は增大する事を報告し

Table 8. Effects of thyroidectomy or hexestrol, estradiol and dexamethasone on the plasma cholesterol and phospholipid levels in the thyroidectomized male rats $^{\mathrm{a}}$ )

\begin{tabular}{c|c|c|c|c}
\hline \multirow{2}{*}{} & \multicolumn{2}{|c|}{ Total cholesterol $(\mathrm{mg} / \mathrm{dl})$} & \multicolumn{2}{|c}{ Phospholipid (mg/dl) } \\
\cline { 2 - 5 } & Control & Treated & Control & Treated \\
\hline \hline Thyroidectomy $^{\mathrm{b})}$ & $67.7 \pm 2.62^{\mathrm{d})}$ & $59.4 \pm 1.83^{* \mathrm{~d})}$ & $101.9 \pm 3.80^{\mathrm{d})}$ & $87.9 \pm 2.25^{* \mathrm{~d})}$ \\
$"$ " & $71.8 \pm 3.27$ & $62.7 \pm 1.67^{*}$ & $114.5 \pm 6.44$ & $84.1 \pm 1.12^{*}$ \\
$"$ & $88.9 \pm 1.71$ & $53.5 \pm 2.28^{*}$ & $108.6 \pm 4.26$ & $66.2 \pm 3.32^{*}$ \\
$"$ & $68.6 \pm 1.76$ & $81.1 \pm 3.95^{*}$ & $111.9 \pm 4.87$ & $109.0 \pm 10.44$ \\
Hexestrol $^{\mathrm{c}}$ & $53.5 \pm 2.28$ & $33.4 \pm 2.66^{*}$ & $66.2 \pm 3.32$ & $44.1 \pm 4.51^{*}$ \\
Estradiol $^{\mathrm{c}}$ & $81.1 \pm 3.95$ & $54.7 \pm 2.11^{*}$ & $109.0 \pm 10.44$ & $89.9 \pm 4.80^{*}$ \\
Dexamethasone $^{\mathrm{c})}$ & $81.1 \pm 3.95$ & $148.4 \pm 10.49^{*}$ & $109.0 \pm 10.44$ & $197.0 \pm 11.26^{*}$ \\
\hline
\end{tabular}

* Statistically significant at $95 \%$ or more of probability against control.

a) Thyroidectomy was performed eleven days before autopsy.

b) The effect of thyroidectomy was compared against the levels of intact animals.

c) Daily $300 \mu \mathrm{g}$ per rat of compounds were injected subcutaneously for the last three days before autopsy.

d) Mean \pm S.E. 
ているが，乙れは術後 6 〜 8 ケ以降汇初めて認められる変化である。甲状腺機能低下時には血中 cholesterol 值の增加，九進時には低下を来す事は広く知られているが，10日間前後の短期間では甲状腺機能の変 化以上に手術に依る食餌掑取量の低下に基く cholesterol 值の変動の方が大きく関係していると思はれる.

甲状腺剔出の影響は以上述べた如く，一般に血漿脂質值の低下を招来するが甲状腺剔出動物に hexestrol, estradiol を投与すると正常動物に対する時と同様に顕著な cholesterol 值の低下が涊められる。一方， dexamethasone は正常動物に於けると同様に著しい脂質值の增大を来す，従つて，estrogen の血漿 cholesterol 低下作用が下垂体甲状腺系を介して発現する可能性も否定出来る.

以上, 正常動物, 下垂体摘出動物, 及び副腎, 性腺, 甲状腺除去動物住対する hexestrol, estradiol, dexamethasone 投与の血漿 cholesterol 值に対する影響を検討したが，結果を綜活すると Table 9 の如く表わ せる。 estrogen の血漿 cholesterol 值低下作用は下垂体摘出に依つてのみ消失し，下垂体の支配下に有る内 分泌葴器除去動物に於ては顕著に，しかも正常動物に於けると同程度に現われる事が明らかになつた。この 事は Estrogen の脂質に対する作用が発現する為には下垂体の機能が必要であり，しかもそれは他の内分泌 系とは関係のない作用に基くものである事を示唆する. 従つて, 次に(2)の可能性について検討を試みた。

Table 9. Comparison of the effects of hexestrol, estradiol and dexamethasone on the plasma cholesterol level in the intact, hypophysectomized, adrenalectomized, castrated or thyroidectomized male rats

\begin{tabular}{l|c|c|c}
\hline & Hexestrol & Estradiol & Dexamethasone \\
\hline Intact & decrease & decrease & increase \\
Hypophysectomized & no change & no change & increase \\
Adrenalectomized & decrease & decrease & increase \\
Castrated & decrease & decrease & increase \\
Thyroidectomized & decrease & decrease & increase \\
\hline
\end{tabular}

\section{Hexestrol の作用と下垂体 homogenate との関係}

下垂体摘出ラットに於て estrogen の血漿cholesterol 低下作用の消失する原因が下垂体に由来する物質の 欠如に基くものであるならば，下垂体摘出動物に下垂体 homogenate を投与しておけば estrogen の作用は 発現するであらう事が想像出来る。乙の項に於ては，下垂体 homogenate を投与して estrogen の cholesterol 低下作用が回復するか不か，即ち，estrogen の作用に対する下垂体の役割がその下垂体由来の物質に 基くものか, 又はその機能に基くものであるかを検討した. 即ち, Wistar 系雄ラットの下垂体を約 $3 \mathrm{~g}$ 集め, 生理食塩水で $50 \%$-homogenate を作製した。集めた下垂体は使用時迄生理食塩水中に凍結して保存し，使 用時 homogenate とした。動物の下垂体摘出後 4 日目より上記の下垂体 homogenate をラット当り $0.1 \mathrm{ml}$ を 1 日 1 回 4 日間に渉り皮下注射に依り連続投与した。下垂体 homogenate 投与最終日にラット当り $300 \mu \mathrm{g}$ の hexestrol を皮下注射に依り 1 回投与し，24時間後に血漿脂質值を測定した。測定結果は Table 10 亿示 す如く，下垂体摘出ラットに下垂体 homogenate 投与の前処置をする事に依り estrogen の血漿 cholesterol 低下作用は明らかに発現する。乙の事から estrogen の cholesterol 低下作用の発現には下垂体江由来する 物質が関与している事が考学られる，従つて，次に種々の下垂体性 trophic hormone に依る前処置の影響 を検討した.

\section{Hexestrol の作用と TSH との関係}

下垂体摘出後 4 日目より，ラット当り 1 日量 1.48U.S.P. 単位の TSH を 1 日 1 回，4 日間に渉り生理食 塩水溶液として皮下注射に依り連続投与し, TSH 投与最終日にラット当り $300 \mu \mathrm{g} の$ hexestrol を投与した. 測定結果は Table 11 亿示す如く, TSH 前処置ラットに於ても無処置の下垂体摘出ラットに於けると同様 に， estrogen の作用は発現しない，従つて，TSH は estrogen の血漿 cholesterol 低下作用に関係する下 
Table 10. Effects of hexestrol on the plasma cholesterol, phospholipid, C/P ratio and certain organ weights in the hypophysectomized male rats treated with and without pituitary homogenate

\begin{tabular}{l|c|c|c|c}
\hline \multirow{2}{*}{} & \multicolumn{2}{|c|}{ Non-treated } & \multicolumn{2}{c}{ Pituitary homogenate-treated $^{\mathrm{a})}$} \\
\cline { 2 - 5 } & Control & Hexestrol $^{\mathrm{b}}$ & Control $^{\text {Hexestrol }}{ }^{\mathrm{b})}$ \\
\hline \hline No. of rats & 5 & 4 & 5 & 5 \\
Body weight (g) & $\left.126.2 \pm 3.34^{\mathrm{c}}\right)$ & $\left.132.0 \pm 4.78^{\mathrm{c}}\right)$ & $\left.167.6 \pm 7.20^{\mathrm{c}}\right)$ & $\left.156.4 \pm 5.44^{\mathrm{c}}\right)$ \\
Thyroid (mg) & $15.1 \pm 0.50$ & $12.8 \pm 1.05$ & $28.3 \pm 1.39$ & $24.7 \pm 2.60$ \\
Adrenals (mg) & $16.6 \pm 0.46$ & $16.0 \pm 1.87$ & $28.6 \pm 2.18$ & $26.7 \pm 0.80$ \\
S. Vesicle (mg) & $36.3 \pm 5.95$ & $40.4 \pm 7.42$ & $95.4 \pm 11.43$ & $89.8 \pm 8.56$ \\
V. Prostate (mg) & $16.4 \pm 1.24$ & $15.0 \pm 1.60$ & $86.8 \pm 17.31$ & $78.0 \pm 8.85$ \\
Plasma total cholesterol (mg/dl) & $92.2 \pm 9.91$ & $76.3 \pm 4.25$ & $82.8 \pm 2.56$ & $53.4 \pm 2.17^{*}$ \\
Plasma phospholipid (mg/dl) & $84.4 \pm 5.74$ & $83.6 \pm 6.64$ & $91.8 \pm 4.63$ & $80.2 \pm 3.26$ \\
C/P ratio & $1.10 \pm 0.100$ & $0.92 \pm 0.04 .5$ & $0.91 \pm 0.048$ & $0.67 \pm 0.036$ \\
\hline
\end{tabular}

* Statistically significant at $95 \%$ or more of probability against control.

a) Daily $0.1 \mathrm{ml}$ of $50 \%$ rat pituitary homogenate was injected subcutaneously for the last four days before autopsy.

b) A day before autopsy, $300 \mu \mathrm{g}$ per rat of hexestrol was injected subcutaneously.

c) Mean \pm S.E.

Table 11. Effects of hexestrol on the plasma cholesterol and phospholipid levels in the hypophysectomized male rats treated with and without TSH

\begin{tabular}{l|c|c|c|c}
\hline & \multicolumn{2}{|c|}{ Non-treated } & \multicolumn{2}{|c}{ TSH-treated $^{\text {a) }}$} \\
\cline { 2 - 5 } & Control & Hexestrol $^{\mathrm{b})}$ & Control & Hexestrol $^{\mathrm{b})}$ \\
\hline No. of rats & 5 & 4 & 5 & 6 \\
Body weight (g) & $\left.126.2 \pm 3.34^{\mathrm{c}}\right)$ & $\left.132.0 \pm 4.78^{\mathrm{c}}\right)$ & $\left.131.2 \pm 3.72^{\mathrm{c}}\right)$ & $\left.132.2 \pm 3.29^{\mathrm{c}}\right)$ \\
Plasma total cholesterol (mg/dl) & $92.9 \pm 9.91$ & $76.3 \pm 4.25$ & $75.4 \pm 4.07$ & $69.3 \pm 1.52$ \\
Plasma phospholipid (mg/dl) & $84.4 \pm 5.74$ & $83.6 \pm 6.64$ & $65.9 \pm 9.57$ & $76.1 \pm 8.71$ \\
C/P ratio & $1.10 \pm 0.100$ & $0.92 \pm 0.045$ & $1.21 \pm 0.126$ & $0.97 \pm 0.117$ \\
\hline
\end{tabular}

a) Daily 1.48 USP per rat of TSH (U.S.P. Thyrotropin Reference Standard) was injected subcutaneously for the last four days before autopsy.

b) A day before autopsy, $300 \mu \mathrm{g}$ per rat of hexestrol was injected subcutaneously.

c) Mean \pm S.E.

垂体成分中の因子ではない事が結論出来る。尚，ての実験は先の下垂体 homogenate との関係を検討した 実験と平行して行つたものであるので，下垂体摘出群の值は Table 10 と同一である．ての結果から，先の 下垂体 homogenate 投与群に於ける hexestrol の血漿 cholesterol 低下作用が顕著なものである事が結論 出来る.

甲状腺及び甲状腺ホルモンの血中 cholesterol 值に及ぼす作用については既に多くの報告がある. Kritchevsky ${ }^{12)}$ の総説によると一般に甲状腺機能低下時には血中 cholesterol 值は増大し，機能九進時，又は甲状腺 ホルモン投与時には低下すると云う。然し，てれらの変化はかなり長期間の処置後に認められるのであつて， 1 日にラット当り $10 ， 50$ ，或は $250 \mu \mathrm{g}$ の-thyroxine t 3 日間皮下注射した我々の実験では Table 12 に示 す如く血漿 cholesterol 值に何等变化を認める事は出来なかつた. 又, Table 13 に示した如く 1 日ラット 
Table 12. Effects of 1-thyroxine on the plasma cholesterol, phospholipid, $\mathrm{C} / \mathrm{P}$ ratio and thyroid weight in the intact male rats

\begin{tabular}{l|c|c|c|c}
\hline & \multirow{2}{*}{ Control } & \multicolumn{2}{|c}{1 -Thyroxine (Daily dose) ${ }^{\mathrm{a})}$} \\
\cline { 3 - 5 } & & $10 \mu \mathrm{g}$ & $50 \mu \mathrm{g}$ & $250 \mu \mathrm{g}$ \\
\hline No. of rats & 8 & 8 & 8 & 8 \\
Body weight (g) & $\left.154.5 \pm 5.05^{\mathrm{b}}\right)$ & $\left.143.0 \pm 2.83^{\mathrm{b}}\right)$ & $\left.150.6 \pm 5.4 .6^{\mathrm{b}}\right)$ & $\left.149.0 \pm 4.69^{\mathrm{b}}\right)$ \\
Thyroid $(\mathrm{mg})$ & $16.0 \pm 0.67$ & $12.0 \pm 0.69^{*}$ & $14.0 \pm 0.84$ & $15.9 \pm 0.86$ \\
Plasma total cholesterol (mg/dl) & $91.0 \pm 2.76$ & $94.5 \pm 3.02$ & $96.6 \pm 3.95$ & $93.6 \pm 4.03$ \\
Plasma phospholipid (mg/dl) & $109.0 \pm 6.06$ & $111.4 \pm 4.18$ & $132.1 \pm 5.07^{*}$ & $137.2 \pm 7.62^{*}$ \\
C/P ratio & $0.85 \pm 0.033$ & $0.85 \pm 0.014$ & $0.73 \pm 0.013^{*}$ & $0.69 \pm 0.020^{*}$ \\
\hline
\end{tabular}

* Statistically significant at $95 \%$ or more of probability against control.

a) 1-Thyroxine injected subcutaneously for three days.

b) Mean \pm S.E.

Table 13. Effects of orally administered thiouracyl on the plasma cholesterol, phospholipid, $\mathrm{C} / \mathrm{P}$ ratio and certain organ weights in the intact male rats.

\begin{tabular}{l|c|c}
\hline \hline & Control & ${\text { Thiouracy } \mathrm{l}^{\mathrm{a}} \text { ) }}$ \\
\hline \hline No. of rats & 6 & 8 \\
Body weight (g) & $299.0 \pm 8.14^{\mathrm{b})}$ & $\left.270.4 \pm 11.40^{\mathrm{b}}\right)$ \\
Thyroid (mg) & $25.5 \pm 2.76$ & $42.0 \pm 4.01^{*}$ \\
Pituitary (mg) & $9.42 \pm 0.49$ & $9.04 \pm 0.43$ \\
Thymus (mg) & $317.7 \pm 20.20$ & $276.8 \pm 14.58$ \\
Adrenals (mg) & $42.5 \pm 1.32$ & $44.7 \pm 1.41$ \\
S. Vesicle (mg) & $484.0 \pm 24.30$ & $362.5 \pm 44.76^{*}$ \\
V. Prostate (mg) & $373.6 \pm 10.55$ & $403.8 \pm 40.86$ \\
Plasma total cholesterol (mg/dl) & $84.7 \pm 3.06$ & $91.6 \pm 3.06$ \\
Plasma phospholipid (mg/dl) & $111.5 \pm 2.74$ & $135.6 \pm 0.71^{*}$ \\
C/P ratio & $0.77 \pm 0.044$ & $0.66 \pm 0.019$ \\
\hline
\end{tabular}

* Statistically significant at $95 \%$ or more of probability against control.

a) Thiouracyl was administered orally daily $5 \mathrm{mg}$ per rat for 52 days.

b) Mean \pm S.E.

当り $5 \mathrm{mg}$ の thiouracyl を52日間に渉り経口投与した実験では甲状腺重量は著しく増大したにもかかわらず 血漿脂質值はわづかに増加したに過ぎなかつた。此の成績は「estrogen の脂質に対する作用は甲状腺の機能 を介して発現するのではないか」という Farbmann ${ }^{9}$ の考え方を支持していない．従つて，甲状腺機能の影響 は今回の下垂体摘出の影響とは切り離して別個倹討されねばならないと思われる。

\section{Hexestrol の作用と ACTH との関係}

ACTH には周知の如く副腎外作用として脂肪動員作用 (lipid-mobilizing effect) を有する事が in vivo $^{13,14)}$ ，及び in vitro $\left.{ }^{15}, 16\right)$ の実験で立証されている。 そてでての項に於ては ACTH が下垂体摘出動物に 於て estrogen の血漿 cholesterol 低下作用発現の為の因子になり得るか否かを検討した。即ち，下垂体摘 出後 5 日目より AGTH を 1 日 3 回（9時, 17時, 及び22時), 毎回 4 I.U./rat づつ計 12 I.U./day/rat を 4 日間に渉り皮下注射化侬り連続投与した。又，ACTH 投与開始後 2 日目より 1 日量 $300 \mu \mathrm{g}$ の hexestrol te 3 日間, 皮下注射に依り同時投与した，測定結果は Table 14 に示す如くである. 先にも示した如く下垂体 
Table 14. Effcts of hexestrol and/or ACTH on the plasma cholesterol and phospholipid levels in the hypophysectomized male rats

\begin{tabular}{|c|c|c|c|c|}
\hline \multirow{2}{*}{ Treatment } & \multicolumn{2}{|c|}{ Total cholesterol $(\mathrm{mg} / \mathrm{dl})$} & \multicolumn{2}{|c|}{ Phospholipid (mg/dl) } \\
\hline & Control $^{c}$ ) & Treated & Control $\left.^{c}\right)$ & Treated \\
\hline Hexestrol $\left.^{a}\right)$ & $70.7 \pm 4.35^{\mathrm{d})}$ & $68.5 \pm 3.56^{\mathrm{d})}$ & $56.0 \pm 8.12^{\mathrm{d})}$ & $52.5 \pm 4.48^{d)}$ \\
\hline $\mathrm{ACTH}^{\mathrm{b})}$ & $70.7 \pm 4.35$ & $101.9 \pm 4.59 *$ & $56.0 \pm 8.12$ & $112.5 \pm 6.51 *$ \\
\hline $\mathrm{ACTH}^{\mathrm{b})}$ & $60.8 \pm 3.87$ & $143.8 \pm 16.4^{*}$ & $67.7 \pm 8.36$ & $101.0 \pm 7.50 *$ \\
\hline Hexestrol $\left.\left.^{\mathrm{a}}\right)+\mathrm{ACTH}^{\mathrm{b}}\right)$ & $70.7 \pm 4.35$ & $75.1 \pm 3.58$ & $56.0 \pm 8.12$ & $85.0 \pm 7.38^{*}$ \\
\hline Hexestrol $\left.^{\mathrm{a}}\right)+\mathrm{ACTH}^{\mathrm{b}}{ }^{\mathrm{s}}$ & $60.8 \pm 3.85$ & $89.7 \pm 5.21^{*}$ & $67.7 \pm 8.36$ & $62.9 \pm 4.54$ \\
\hline
\end{tabular}

* Statistically significant at $95 \%$ or more of probability against control.

a) Daily $300 \mu \mathrm{g}$ per rat of hexestrol was injected subcutaneously for the last three days before autopsy.

b) Daily 12 I.U. per rat of ACTH (Acthar gel, Armour.) was injected subcutaneously three times a day for the last four days before autopsy.

c) Hypophysectomized control group.

d) Mean \pm S.E.

摘出ラットでは hexestrol の作用は現われないが，ACTH 単独投与群では顕著な血漿 cholesterol, phospholipid 值の増加が認められ, ACTH, hexestrol 同時投与群では下垂体摘出対照群と比較して増加, 又は 増加の傾向が認められたが ACTH 単独投与群に比較すると遙かに低い值を示した.

ACTH を下垂体摘出ラットに投与すると Table 14 亿示す如く血漿脂質值の増大が認められるが，同一 の実験条件で正常動物に投与すると Table 15 亿示す如く何等変化は認められないか, 又は寧ろ低下の傾向 さえ示す. Rosenman たち も ACTH 投与は正常動物では血清 cholesterol 值に何等変化を与えないと報告 している. ACTH に関するこの現象の機構は不明であるが，少くとも下垂体摘出動物に於て ACTH は血 漿 cholesterol 值増大作用を有する様に思われる。次に，ACTH を投与した下垂体摘出ラットに hexestrol を同時投与すると， ACTH 単独投与群と比較して血漿脂質值は低下を示し，その值は下垂体摘出対照群と ほぼ同程度である。乙の事から，ACTH が存在すれば estrogen の作用は現われるかの如く思われるが， 然し，もしも ACTH が estrogen の血漿 cholesterol 低下作用に関係する因子であるならば ACTH, hexestrol 同時投与群の示す值は先に下垂体 homogenate を用いた回復試験で得られた如く, 下垂体摘出対照 群に比して血漿 cholesterol 值の著しい低下が認められねばならない. 処が Table 14 の成績はての推論を 支持していない. 従つて, Table 14 の結果は ACTH に血漿 chəlasterol 増大作用が有り, hexestrol はこ

Table 15. Effects of AGTH on the plasma cholesterol, phospholipid and $\mathrm{C} / \mathrm{P}$ ratio in the intact male rats

\begin{tabular}{l|c|c}
\hline \hline & Control & AGTH $^{\mathrm{a}}$ ) \\
\hline No. of rats & 8 & 7 \\
Body weight $(\mathrm{g})$ & $205.0 \pm 3.07 \mathrm{~b})$ & $\left.177.3 \pm 6.53^{\mathrm{b}}\right)$ \\
Plasma total cholesterol $(\mathrm{mg} / \mathrm{dl})$ & $73.8 \pm 2.15$ & $69.6 \pm 3.04$ \\
Plasma phospholipid $(\mathrm{mg} / \mathrm{dl})$ & $144.6 \pm 7.89$ & $138.1 \pm 7.99$ \\
C/P ratio & $0.52 \pm 0.016$ & $0.51 \pm 0.034$ \\
\hline
\end{tabular}

\footnotetext{
a) Daily 12 I.U. per rat of AGTH (Acthar gel, Armour.) was injected subcutaneously three times a day for the last three days before autopsy.

b) Mean \pm S.E.
} 
れを抑制すると考えるのが妥当と思われる。ACTHが estrogen の cholesterol 低下作用に関係する因子で ないととは次の prednisolone 前処置ラットを用いた実験からも支持出来る，即ち，正常動物に corticoid を大量投与すると ACTH 分泌㑉する限り，いわゆる chemical hypophysectomy の状態になる事は良 く知られた事実である。この現象を利用して estrogen の血漿 cholesterol 低下作用に対するACTH の影 響を検討した，正常ラットに 1 日量 $300 \mu \mathrm{g} の$ prednisolone を 8 日間に涉り皮下注射し，最後の 3 日間は同 ビく 1 日量 $300 \mu \mathrm{g} の$ hexestrol を皮下注射化依同時投与した。尚，使用した prednisolone の用量は 5 日 目には血中 11-hydroxycorticosteroids 量を95\%減少させるのに立分な量である。測定結果は Table 16 に 示す如く, prednisolone 処置では血漿 cholesterol, phospholipid 両值は何等変化を受けないが副腎重量は 著しく低下している。即ち，ACTH の分泌は抑制されていると思われる。乙の様なラットに hexestrol t 同時投与すると血漿 cholesterol，phospholipid 両优は顕著に低下し，正常ラットに hexestrol を投与した 対照群の示す低下を凌駕する減少を示した。この事は ACTH が分泌されなくても estrogen の血漿 cholesterol 低下作用が発現するてとを示している。更に, prednisolone 前処置群では hexestrol の作用が prednisolone 非処置群よりも強く現われているが，乙れは先に認められた現象，即ち，下垂体摘出動物では ACTH は血漿 cholesterol 増大作用在示すが， hexestrol はACTH のこの増大作用に拮抗するという成 績と関連しているものと考朰れる。

Table 16. Effects of hexestrol and/or prednisolone pre-treatment on the plasma cholesterol, phospholipid, $\mathrm{C} / \mathrm{P}$ ratio, pituitary and adrenals weights in male rats

\begin{tabular}{|c|c|c|c|c|}
\hline & Control & Hexestrol $\left.^{\mathrm{a}}\right)$ & Prednisolone $^{\mathrm{b})}$ & $\begin{array}{l}\text { Hexestrol }{ }^{\mathrm{a}}{ }^{2} \& \\
\text { Prednisolone }^{\mathrm{b}}\end{array}$ \\
\hline No. of rats & 10 & 10 & 9 & 10 \\
\hline Body weight (g) & $177.1 \pm 6.05^{\mathrm{c})}$ & $\left.137.6 \pm 2.37^{\mathrm{e}}\right)$ & $152.7 \pm 2.71^{\mathrm{c})}$ & $149.6 \pm 4.26^{\mathrm{c})}$ \\
\hline Pituitary (mg) & $5.6 \pm 0.16$ & $6.7 \pm 0.25 *$ & $5.9 \pm 0.15$ & $6.9 \pm 0.33 *$ \\
\hline Adrenals (mg) & $32.6 \pm 1.10$ & $42.9 \pm 1.10^{*}$ & $25.3 \pm 1.42 *$ & $28.5 \pm 1.04 *$ \\
\hline Plasma total cholesterol $(\mathrm{mg} / \mathrm{dl})$ & $75.8 \pm 2.66$ & $40.8 \pm 1.65^{*}$ & $73.6 \pm 1.68$ & $31.3 \pm 1.33 *$ \\
\hline Plasma phospholipid $(\mathrm{mg} / \mathrm{dl})$ & $111.0 \pm 5.50$ & $62.2 \pm 4.94 *$ & $108.3 \pm 4.98$ & $30.4 \pm 2.39 *$ \\
\hline $\mathrm{C} / \mathrm{P}$ ratio & $0.68 \pm 0.019$ & $0.67 \pm 0.034$ & $0.69 \pm 0.028$ & $1.03 \pm 0.050 *$ \\
\hline
\end{tabular}

* Statistically significant at $95 \%$ or more of probability against control.

a) Daily $300 \mu \mathrm{g}$ per rat of hexestrol was injected subcutaneously for the last three days before autopsy.

b) Daily $300 \mu \mathrm{g}$ per rat of prednisolone was injected subcutaneously for the last eight days before autopsy.

c) Mean \pm S.E.

以上，(a) ACTH で前処置した下垂体摘出ラットに hexestrol を投与した場合，血漿 cholesterol 值は下 垂体摘出対照群の血漿 cholesterol 值と大差ない事, (b) ACTH 分泌を充分抑制し得る量の prednisolone 投与ラットに於て hexestrol は顕著な血漿 cholesterol 低下作用を示す事，等の理由に依り ACTH が estrogen の血漿 cholesterol 低下作用に関係する因子ではない事が結論出来る.

\section{Hexestrol の作用と gonadotropin との関係}

下垂体摘出後 4 日目よりラット当り 1 日量 100 I.U.の HCG，又は，PMS 生理食壏水溶液として皮下注 射に依り 4 日間連続投与し，最終注射日に $300 \mathrm{ig} の$ hexestrol を同時投与した. HCG 投与時の測定結果を Table 17 そ, PMS 投与時の結果艺 Table 18 に示す。乙れら 2 つの結果から明らかの様に HCG, 又は, PMS の前処置をした下垂体摘出ラットに対して hexestrol は何等作用を示していない. 従つて，乙れらの gonadotropins も estrogen の血漿 cholesterol 低下作用には関係していない事が考えられる. 
Table 17. Effects of hexestrol on the plasma cholesterol, phospholipid, and C/P ratio in the hypophysectomized male rats treated with and without HCG

\begin{tabular}{l|c|c|c|c}
\hline & \multicolumn{2}{|c|}{ Non-treated } & \multicolumn{2}{c}{ HCG-treated $^{\text {a) }}$} \\
\cline { 2 - 5 } & Control & Hexestrol $\left.{ }^{\mathrm{b}}\right)$ & Control $^{\text {Hexestrol }}{ }^{\mathrm{b})}$ \\
\hline No. of rats & 8 & 8 & 9 & 8 \\
Body weight $(\mathrm{g})$ & $\left.127.6 \pm 3.17^{\mathrm{c}}\right)$ & $\left.122.5 \pm 2.32^{\mathrm{c}}\right)$ & $\left.124.4 \pm 5.36^{\mathrm{c}}\right)$ & $\left.126.8 \pm 4.23^{\mathrm{c}}\right)$ \\
Plasma total cholesterol $(\mathrm{mg} / \mathrm{dl})$ & $70.4 \pm 4.70$ & $60.1 \pm 2.56$ & $75.7 \pm 3.27$ & $64.6 \pm 2.95$ \\
Plasma phospholipid $(\mathrm{mg} / \mathrm{dl})$ & $52.7 \pm 10.4$ & $53.0 \pm 6.68$ & $70.7 \pm 3.82$ & $49.0 \pm 5.31$ \\
G/P ratio & $1.27 \pm 0.166$ & $1.27 \pm 0.178$ & $1.09 \pm 0.054$ & $1.44 \pm 0.173$ \\
\hline
\end{tabular}

a) Daily 100 I.U. per rat of Primogonyl (Choriongonadotropin, Schering Co.) was injected subcutaneously for the last four days before autopsy.

b) A day before autopsy, $300 \mu \mathrm{g}$ per rat of hexestrol was injected subcutaneously.

c) Mean \pm S.E.

Table 18. Effects of hexestrol on the plasma cholesterol, phospholipid and C/P ratio in the hypophysectomized male rats treated with and without PMS

\begin{tabular}{l|c|c|c|c}
\hline & \multicolumn{2}{|c|}{ Non-treated } & \multicolumn{2}{c}{ PMS-treated $^{\mathrm{a}}$ ) } \\
\cline { 2 - 5 } & Control & Hexestrol & Control & Hexestrol $^{\mathrm{b}}$ ) \\
\hline \hline No. of rats & 8 & 8 & 6 & 7 \\
Body weight (g) & $\left.154.8 \pm 6.20^{\mathrm{c}}\right)$ & $\left.159.4 \pm 7.20^{\mathrm{c}}\right)$ & $\left.170.8 \pm 6.29^{\mathrm{c}}\right)$ & $\left.148.7 \pm 4.96^{\mathrm{c}}\right)$ \\
Plasma total cholesterol $(\mathrm{mg} / \mathrm{dl})$ & $89.4 \pm 9.90$ & $65.8 \pm 3.52$ & $84.3 \pm 4.16$ & $71.9 \pm 7.04$ \\
Plasma phospholipid (mg/dl) & $76.1 \pm 3.23$ & $65.7 \pm 2.70^{*}$ & $71.8 \pm 3.44$ & $61.7 \pm 7.18$ \\
C/P ratio & $1.16 \pm 0.077$ & $1.00 \pm 0.050$ & $1.18 \pm 0.065$ & $1.22 \pm 0.122$ \\
\hline
\end{tabular}

* Statistically significant at $95 \%$ or more of probability against control.

a) Daily 100 I.U. per rat of Anterone (Gonadotropes hormon aus Serum, Schering Co.) was injected subcutaneously for the last four days before autopsy.

b) A day before autopsy, $300 \mu \mathrm{g}$ per rat of hexestrol was injected subcutaneously.

c) Mean \pm S.E.

Table 19. Effects of hexestrol on the plasma cholesterol, phospholipid and $\mathrm{C} / \mathrm{P}$ ratio in the hypophysectomized male rats treated with and without growth hormone

\begin{tabular}{|c|c|c|c|c|}
\hline & \multicolumn{2}{|c|}{ Saline } & \multicolumn{2}{|c|}{ Growth hormone $^{\text {a) }}$} \\
\hline & Control & Hexestrol $\left.^{b}\right)$ & Control & Hexestrol $\left.{ }^{b}\right)$ \\
\hline No. of rats & 7 & 7 & 7 & 7 \\
\hline Body weight (g) & $\left.143.3 \pm 3.88^{\mathrm{c}}\right)$ & $\left.132.9_{ \pm}+08^{\mathrm{c}}\right)$ & $157.7 \pm 5.54^{\mathrm{c})}$ & $161.7 \pm 5.37^{\mathrm{c})}$ \\
\hline Plasma total cholesterol $(\mathrm{mg} / \mathrm{dl})$ & $81.3 \pm 6.12$ & $85.5 \pm 5.77$ & $69.8 \pm 3.37$ & $53.7 \pm 1.47 *$ \\
\hline Plasma phospholipid (mg/dl) & $63.2 \pm 4.85$ & $62.3 \pm 3.75$ & $61.0 \pm 2.37$ & $43.3 \pm 2.91 *$ \\
\hline $\mathrm{G} / \mathrm{P}$ ratio & $1.31 \pm 0.093$ & $1.37 \pm 0.041$ & $1.15 \pm 0.053$ & $1.26 \pm 0.065$ \\
\hline
\end{tabular}

* Statistically significant at $95 \%$ or more of probability against control group.

a) Daily 1 unit per rat of growth hormone (Antuitrin Growth ; Parke, Davis \& Company, U.S.A.) was injected for the last four days before autopsy.

b) A day before autopsy, $300 \mu \mathrm{g}$ per rat of hexestrol was injected subcutaneously.

c) Mean \pm S.E. 
Table 20. Effects of hexestrol on the plasma cholesterol and phospholipid levels in the hypophysectomized male rats treated with different growth hormones

\begin{tabular}{|c|c|c|c|c|}
\hline Experiment & Treatment & $\begin{array}{c}\text { No. of } \\
\text { rats }\end{array}$ & $\begin{array}{c}\begin{array}{c}\text { Total cholesterol } \\
(\mathrm{mg} / \mathrm{dl})\end{array} \\
\end{array}$ & $\begin{array}{c}\text { Phospholipid } \\
(\mathrm{mg} / \mathrm{dl})\end{array}$ \\
\hline \multirow{3}{*}{ I } & Control & 7 & $91.2 \pm 2.66$ & $83.3 \pm 2.10$ \\
\hline & Growth hormone ${ }^{a}$ ) & 8 & $75.6 \pm 1.51 *$ & $78.4 \pm 1.36$ \\
\hline & Growth hormone $e^{a}+$ Hexestrol & 8 & $53.7 \pm 3.29^{*}$ & $65.9 \pm 3.77$ \\
\hline \multirow{3}{*}{ II } & Control & 8 & $93.4 \pm 6.85$ & $85.4 \pm 6.02$ \\
\hline & Growth hormone ${ }^{b}$ ) & 8 & $78.9 \pm 3.42$ & $76.2 \pm 2.71$ \\
\hline & Growth hormone $\left.{ }^{b}\right)+$ Hexestrol & 9 & $61.0 \pm 1.98^{*}$ & $55.0 \pm 3.32 *$ \\
\hline
\end{tabular}

* Statistically significant at $95 \%$ or more of probability against control.

a) Antuitrin Growth, daily 1 unit per rat, was injected for the last four days before autopsy.

b) U.S.P. Growth Hormone Reference Standard, daily $625 \mu \mathrm{g}$ per rat, was injected for the last four days before autopsy.

\section{Hexestrol の作用と growth hormone (STH) との関係}

下垂体摘出後 4 日目より 4 日間に渉り growth hormone を 1 日 1 回，生理食塩水溶液として皮下注射に 依り投与し，最終注射日に $300 \mu \mathrm{g} の$ hexestrol t 1 回投与した. U.S.P. Growth Hormone Reference Standard は 2.5mg/rat/day, Antuitrin Growth は 1 unit/rat/day の用量で使用した. 測定結果は Table 19, 及び Table 20 に示す如くである。下垂体摘出ラットに hexestrol を投与した場合は今迄も度々示した様に 血漿脂質値の低下は認められない. Growth hormone 単独投与で cholesterol 值, phospholipid 值共に低 下の傾向を示すが推計学的に有意の変化ではない. 処が，growth hormone を処置した下垂体摘出ラットに hexestrol を投与すると血漿 cholesterol 值, phospholipid 值の顕著な低下が認められる。この低下は下垂 体摘出刘照群に対しては勿論, growth hormone 処置対照群に対しても推計学的に95\%以上の信頼度で有意 である。

従つて，てれら一連の実験から estrogen の血漿 cholesterol 低下作用に関係する因子は growth hormone であろうと考えられる。

\section{考 察}

Growth hormone を投与した下垂体摘出ラットに於て，hexestrol の作用が回復しているか否かを検討す る為に前述の5.-9.で得られた成績について血漿 cholesterol 值, phospholipid 值の\%变化を Table 21 に まとめた，ての Table に於て值は全て，処置群の示した值の対照群の值に対する百分率（\%）で示してあ る. TCは cholesterol 值, PL は phospholipid 值であるが hexestrol 投与群の值は, 欄の左側に下垂体摘出 対照群に対する割合, 右側に各種 trophic hormone 処置を行つた下垂体摘出対照群に対する割合を示した。 又, hexestrol 非投与群の值は各種 trophic hormone 処置群の示した值の下垂体摘出対照群に対する割合で ある．また Table 22 に示す如く，正常ラットに hexestrol を投与した場合12時間後では cholesterol 值は 85\%に減少し，24時間後には cholesterol 值は49\%に，phospholipid 值は54\%に減少する。更に，3 日間連 続投与すると cholesterol 值は $45 \%$ 亿, phospholipid 值は $54 \%$ に減少する. 然し, 下垂体摘出ラットに対し ては Table 1, 及び Table 21 に示した如く, hexestrol を 3 日間投与した場合に於てすらその作用は全く 現われない，一方，下垂体 homogenate を投与した下垂体摘出ラットに於て hexestrol は血漿 cholesterol 值を58\%と顕著に低下させるが phospholipid 值には変化を与えない. これに対し, 各種 trophic hormone (TSH, ACTH, HCG, PMS, STH) 投与群で hexestrol 投与に依り血漿脂質值亚著な低下を示すのは growth hormone 処置群のみであり，しかもその脂質值の低下は下垂体摘出対照群に対して cholesterol 值 
Table 21. Percentage changes in the plasma cholesterol and phospholipid levels produced by the administration of hexestrol to the hypophysectomized male rats pre-treated with rat pituitary homogenate (P.H.), TSH, ACTH, HCG, PMS or growth hormone (GH)

\begin{tabular}{|c|c|c|c|c|c|c|}
\hline \multirow{2}{*}{$\begin{array}{c}\text { Pre- } \\
\text { treatment }\end{array}$} & \multicolumn{4}{|c|}{ Hexestrol } & \multicolumn{2}{|c|}{ No Hexestrol } \\
\hline & $\mathrm{TC}^{\mathrm{a})}$ & $P^{a}{ }^{a}$ & $\mathrm{TC}^{\mathrm{b})}$ & $\left.P L^{b}\right)$ & $\mathrm{TC}^{\mathrm{a})}$ & $P L^{a)}$ \\
\hline None & 85 & 91 & - & - & - & - \\
\hline P.H. & $58 *$ & 95 & $64^{*}$ & 87 & 90 & 109 \\
\hline TSH & 75 & 90 & 92 & 115 & 81 & 78 \\
\hline ACTH & 106 & $152 *$ & $74 *$ & 76 & $144 *$ & $201 *$ \\
\hline ACTH & $148 *$ & 93 & $62 *$ & $62^{*}$ & $237 *$ & $149 *$ \\
\hline HGG & 92 & 93 & 85 & 69 & 108 & 134 \\
\hline PMS & 80 & 81 & 85 & 86 & 94 & 94 \\
\hline $\mathrm{GH}^{\mathrm{c})}$ & $59 *$ & $65 *$ & $77 *$ & $72 *$ & 84 & 89 \\
\hline $\mathrm{GH}^{\mathrm{d})}$ & $66 *$ & $69 *$ & $77 *$ & $71^{*}$ & 86 & 97 \\
\hline $\mathrm{GH}^{\mathrm{d})}$ & $65^{*}$ & $79 *$ & $71 *$ & 84 & $83 *$ & 94 \\
\hline
\end{tabular}

TG : total cholesterol in plasma

PL : phospholipid in plasma

* Statistically significant at $95 \%$ or more of probability.

a) The percentage against the level of hypophysectomized control group.

b) The percentage against the level of hypophysectomized and pre-treated group.

c) U.S.P. Growth Hormone Reference Standard

d) Antuitrin Growth
が60\%, phospholipid 值が70\%, 又, growth hormone 処置群に対してそ れぞれ75\%前後と減少する。乙れら の減少度は正常動物, 又は, 下垂体 homogenate 投与動物に於ける変化 に近い值と思われるがその值に迄達 していない点に多少問題が残る。 ACTH 処置 hexestrol 投与群に $\mathrm{ACTH}$ 単独投与群に比して脂質值 の低下が認められるがこの点に関し ては先に7.に於て検討し ACTH が hexestrol の血漿 cholesterol 值低 下作用に直接関係する因子ではない 事を明らかにした，従つて，下垂体 性の物質でしかも estrogen の血漿 cholesterol 值低下作用の発現に関 与している物質は growth hormone であろうと思われる。

脂質代謝に及ぼす growłh hormone の影響は主にエネルギー源と しての脂肪酸代謝の分野で広く検討 され Goodman たち ${ }^{17)}$ ，その他多く の研究者に依り growth hormone 投与が顕著な血中遊離脂肪酸の增量

Table 22. Percentage changes in the plasma cholesterol and phospholipid levels produced by the administration of hexestrol $(300 \mu \mathrm{g} / \mathrm{day} / \mathrm{rat})$ to the intact male rats

\begin{tabular}{|c|c|c|c|}
\hline & \multicolumn{2}{|c|}{ Single injection } & \multirow{2}{*}{$\begin{array}{l}\text { Multiple injection } \\
\text { for } 3 \text { days }\end{array}$} \\
\hline & 12 hrs. later & 24 hrs. later & \\
\hline Total cholesterol ${ }^{\mathrm{a}}$ ) & $85^{*}$ & $49 *$ & $45^{*}$ \\
\hline Phospholipid $\left.^{a}\right)$ & 105 & $54 *$ & $54 *$ \\
\hline
\end{tabular}

* Statistically significant at $95 \%$ or more of probability.

a) The percentage against the level of intact control group

を来す事が報告されているが脂肪酸代謝と cholesterol との関係は明らかでない. Bauman たち ${ }^{18)}$ は下垂体 摘出ラットの肝に於ける cholesterol の生合成が growth hormone 投与に依り増加する事を観察し, Leal

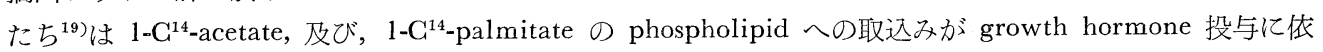
り増加する事を報告しているが今回の我々の結果とどの様な関連が有るか不明である.

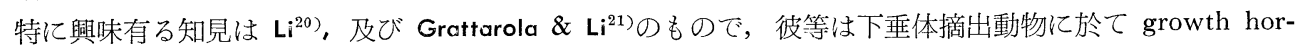
mone に子宮肥大作用が有る事を示し，更に growth hormone の作用は estradiol の子宮肥大作用と協同 的に発現し estradiol 単独投与では微弱な效果しか期待出来ない用量でも growth hormone を同時投与す ると著しい変化が得られる事ヶ見出した。しかも，乙の作用は下垂体性の種々の trophic hormone の中で

$$
\text { 第39巻 第 } 12 \text { 号 }
$$


growth hormone に特異的である。これらの事から $\mathbf{L i}^{20}$ は growth hormone には生長促進ホルモンとして の作用の他に一般的な生物的協同作用物質 (biological synergist) としての性質が有るのではないかと示唆 している.

ACTH の血中 cholesterol 值に対する影響については Rosenman たち ${ }^{6}$ は変化ないと報告しているが Conn たち ${ }^{22)}$, Kyle たち ${ }^{23)}$ cholesterol 值の減少を報告し, Adlersberg たち ${ }^{24)}$ ACTH 投与に依り cholesterol 值は初期に低下するが次いで増加に転ずる事を観察している. Segaloff たち ${ }^{25)}$ ACTH が血中 cholesterol 值の増加を示す事を報告している，我々の実験では，正常ラットでは変化なく下垂体摘出ラットでは 同量の ACTH が顕著な血漿 cholesterol 增加作用を示す成績を得た. 先に引用した Bauman たち ${ }^{13)} の$ 報告 では growth hormone の肝に於ける cholesterol 生合成促進作用は下垂体摘出ラットでは認められるが正 常ラットでは認められない事を述べている。乙れは我々の ACTH の場合と良く似た現象であるが，正常動 物に比して下垂体摘出ラットでは肝の cholesterol 生合成速度が低下するので ${ }^{18,26)}$ ，おながち同一の現象と は云えない. Hill たち ${ }^{27}$ は動物の栄養状態に左右されるのであろうと説明している.

下垂体摘出ラットに ACTH を投与した場合, 興味有る点は ACTH に cholesterol 増大作用が有る事, 及びての作用に hexestrol が拮抗する点である. 下垂体摘出ラットに対しては hexestrol は cholesterol 低 下作用を示さないので，7.で示した結果はAGTH の作用に hexestrol が拮抗すると考えられるが，ての作 用機構は今後に残された問題である.

TSH は人に於ては thyroxine と同様な作用を示し，血漿 cholesterol 值の低下を来す事が Iversen たち ${ }^{28)}$ に依り報告されているが下垂体摘出ラットで検討した我々の結果では変化を認め得なかつた. Thompson た $ち^{29}$ は犬に於て甲状腺機能低下に依る血中 cholesterol 值の増大が下垂体摘出に依り消失するという興味有 る報告をしているが我々の得た今回の成績との関係は未だ明らかでない.

\section{結 語}

Hexestrol, estradiol, 及び estriol の示す血漿 cholesterol 低下作用が下垂体摘出後次第に減少し, 術後 9 日目以降のラットでは完全に消失するが, 副腎, 性腺, 甲状腺等を剔出したのでは消失しない事を見出し た.これに対し, 著しい血漿 cholesterol 值の増加を示す dexamethasone の作用はてれらの手術に依り何 等影響を受けなかつた。

ラットの下垂体摘出後, 同種属の下垂体 homogenate, 又は牛の growth hormone で前処置しておくと hexestrol の血漿 cholesterol 低下作用は現われるが，TSH，HCG，PMS 等の trophic hormone 前処置で は hexestrol の作用は現われなかつた。

これらの事から, estrogen の血漿 cholesterol 低下作用が発現するためには下垂体の存在が必要であり, 下垂体ホルモンのうちでも growth hormone が最も重要な役割を果しているものと推察される。

ACTH は正常ラットの血漿 cholesterol 值に対しては何等作用を示さなかつたが，下垂体摘出ラットに 対しては顕著な血漿 cholesterol 増加作用を示し, この增加作用に対し hexestrol は抑制的に作用したが正 常值以下には減少せしめなかつた。 また，prednisolone 処置に依つて ACTH 分泌を完全に抑制したと思 われるラットでも hexestrol の作用は発現した. 従つて, hexestrol の cholesterol 低下作用発現に関して ACTH は間接的には何等かの関係を持つとしても, 直接的には重要な因子であるとは考えられない.

終りに，御指導御校閲下さいました三宅有博士，及び終始実験に御協力頂いた門脇真澄氏に心から感謝致 しま产.

本論文の要旨は符10回日本内分必学会西日杢地方会 (大阪, 圆37), 及び第23回日本薬理学会近畿部会 (岡 山, 昭38) に招いて発表した。

\section{引用 文 献}

1) LEVIN, L. : Endocrinology, $37: 34$, (1954).

2) PEKKARINEN, A., I. KAPPOLA and L. 
PETRO : Acta Endocrinologica, $10: 212,(1952)$.

3) BOYD, G.S. and W.B. MEGUIRE : Biochem. J., $62: 19 p,(1956)$.

4) BOYD, G.S. : Fed. Proc., 20. sup. : 152, (1961).

5) UCHIDA, K. and T. MIYAKE : Ann. Rept. of Shionogi Res. Lab., $11: 119$, (1961).

6) ROSENMAN, R.H., H. FRIEDMAN and S.O. BYERS : Endocrinology, $51: 142$, (1952).

7) FILLIOS, L.C. : Endocrinology, $60: 22$, (1957) 8) FILLIOS, L.C., R. KAPLAN, R.S. MARTIN and F.J. STARE : Am. J. Physiol., 193 : 47, (1958).

9) FARBMANN, A.A. : J. Clin. Endocrinology, $4: 17$, (1944). 10) MIYAKE, T. : Endocrinology, $69: 534$, (1961).

11) TANAKA, A., Ann. Rept. of Shionogi Res. Lab., $5: 154$, (1955)

12) KRITGHEVSKY, D. : Metabolism

13) ENGEL, F.L. and M.G. ENGEL : Endocrinology, $62: 75$, (1958). F. L. ENGEL : Proc. Soc. Exp. Biol. \& Med., 102 : 272, (1959).

14) WHITE, J.E. and MACLEOD and R.H. BROWN : J. Biol. Chem., 235 : 1904, (1960). 15) LYNN, W.S., R.M. CAHILL : J. Biol. Chem., 236 : 41, (1961). 17) GOODMAN, H.M. and E. KNOBIL : Endocrinology, $65: 451$, (1959). 18) BAUMAN, J.W., R. HILL, N.S. NEJAD and I.L. GHAIKOFF : Endocrinology, $65: 73$, (1959). 19) LEAL, R.S. and A.L. GREENBAUM : Biochem. J., 80 : 27, (1961). 20) LI, C.A. : Science, $123: 617$, (1956).

21) GRATTAROLA, R. and C.H. LI : Endocrinology, $65: 802$, (1959). 22) CONN, J.W., W.C. VOGEL, L.H. LOUIS and S.S. FAJANS : J. Lab. Clin. Med., 35 : 504, (1950). 23) KYLE, L.H., W.C. HESS and W.P. WALSH : J. Lab. Clin. Med., 39 : 65, (1952). 24) ADLERSBERG, D., L.E. SCHAEFER and S.T. DRACHMAN : J. Clin. Endocrinology, $11: 67$, (1951). 25) SEGALOFF, A. and A.S. MANY : Endocrinology, $49: 390$, (1951). $\quad$ 26) THOMKINS, G.M. and I.L. CHAIKOFF : J. Biol. Chem., $196: 569,(1952)$ 27) HILL, R., J.W. BAUMAN and I.L. CHAIKOFF : Endocrinology, 57 : 316, (1955). 28) IVESEN, K. : Acta Endocrinologica, $11: 111,(1952) . \quad 29)$ THOMPSON, K.W. and C.H.N. LONG : Endocrinology, 28 : 715, (1941). 